\title{
THE YOUTH CORRECTION AUTHORITY ACT
}

\author{
JOHN BARKER WAITE*
}

Some fifteen years ago a joint session of committees of the American Law Institute, American Bar Association and the Association of Law Schools considered the wisdom of undertaking a "restatement" of criminal law. Out of this proposal there eventuated, somewhat indirectly, another committee which included psychologists, psychiatrists, criminologists and sociologists interested in related fields, as well as lawyers. This latter committee was emphatically of the opinion that a thoroughgoing revision of the criminal law, rather than a mere restatement, was needed. Proposals to that end were made and some steps taken toward it, but the necessary financial support did not materialize. However, it was recognized at the time that an absolute prerequisite of revision would be clear determination of the purpose to be accomplished by means of the criminal law. That committee in its turn, again with some remote relationship, was followed by the committee, ${ }^{1}$ functioning under the auspices of the American Law Institute, by which the proposed Youth Correction Authority Act was formulated. And again one of the primary problems, requiring solution before detailed drafting of any proposal could be undertaken, was determination of the precise objective whose accomplishment was to be sought.

\section{The Preliminary Probiems}

The objective of any criminal law can be predicated either on hate, or on hope. The purpose may be either retrospective or prospective. But one proposition is indisputable; no part of the criminal law can be soundly formulated until some purpose is definitely agreed upon and adhered to by the formulators. This determination of

*A.B., 1905, Yale University; LL.B., I907, University of Michigan. Member of the Michigan and Ohio Bars. Professor of Law, University of Michigan School of Law, since 1912. Reporter to the American Law Institute's Criminal Justice-Youth Committee which drafted the Youth Correction Authority Act and the Youth Court Act. Member of the United States Supreme Court's Advisory Committec on the Preparation of Rules of Pleading, Practice and Procedure in Criminal Cases. Author of CASEs on Criminat Law and Procedure (193I); Cruminal Law in Action (1938), and a number of other legal works. Contributor to legal and general periodicals.

References to state statutes in this article have been made for purposes of illustration only and hence have not been encumbered by footnote citations.

${ }^{1}$ The following were members of the Committee: William Draper Lewis, Director of the Institute, Chairman; John Barker Waite, University of Michigan Law School, Reporter; Curtis Bok, Prcsident Judge, Court of Common Pleas No. 6, Philadelphia; E. R. Cass, General Secretary, Amcrican Prison Association, New York City; Sheldon Glueck, Harvard University Law School; Lconard V. Harrison, Director, Committee on Youth and Justice, Community Service Society, New York City; Dr. William Healy, Director, Judge Baker Guidance Center, Boston; Edwin R. Keedy, University of Pennsylvania Law School; Austin H. MacCormick, Executive Dircctor, The Osborne Association, New York City; William E. Mikell, University of Pcnnsylvania Law School; Thorsten Scllin, Department of Sociology, University of Pcnnsylvania; ant Joseph N. Ulman, Supreme Bench of Baltimore City, Baltimore. 
the purpose to be accomplished by the new law was thus a necessary preliminary to further work by the drafting committee.

The once widely prevalent philosophy of Kant and Hegel postulated a retrospective purpose. Punishment was conceived as an exaction of regret; it was not even thought of as a measure of prospective utility. One man, declared Kant, ought never to be dealt with merely as a means to an end desired by others; not even as a means of attainment of the public good. Hence, though he might properly be made to suffer for his sins, it was not proper to impose that suffering as an example whereby to influence the conduct of others. In the current philosophy of the period, the punishment of wrongdoers was a religious duty, the exaction of expiation, the imposition of retributory suffering necessary to the rounding out of the harmony of abstract "justice" But it was not suffering imposed as an example to others. ${ }^{2}$ Nor was this notion of retribution for the past, of evening the score by matching evil to be suffered with evil done without specific concern for the future, confined to the expression of lay philosophers; it permeated legal thought as well. Judicial opinions spoke of heavy sentences "in expiation" of wrong done and "in revenge" for injury accomplished; legislators enacted statutes designed for similar purposes. In the words of Sir James Stephen, "the criminal law stands to the passion of revenge in much the same relation as marriage to the sexual appetite."3

But a quite different notion of the value of punishment held place as long ago as Plato and Seneca. Its postulate was that we do not punish a man because he has offended, but that he may offend no more. This, in a revived form, has become the dominant thought, not always adhered to, behind the modern criminal law. Between these two philosophies the committee had to choose, though that choice was easy.

But even the notion of a prospective, preventive purpose in the criminal law has been, as it still is, involved in a confusion of thought. Should the law in its preventive efforts deal with a convicted wrongdoer in the hope that he himself will be thereby induced to offend no more? Or should it be designed primarily to the end that others, who witness the consequences visited upon a discovered criminal, shall take heed and themselves refrain from similar trespassing? Again the committee had to choose. It would not do to answer casually, "both." Time and intelligence have forced us to the realization that consequences which are calculated to beget the greatest fear in those who merely observe them are not also well designed to constrain those who suffer them into the paths of rectitude. The death penalty may do both in a sense; at least, while it perhaps frightens potential offenders, it does also preclude fresh offense by offenders on whom it has been imposed. But the data compiled by such men as Thorsten Sellin demonstrate beyond peradventure that the traditional punitive method of dealing with known criminals, whatever effect it may have in the prevention of potential crime by others, is lamentably unsatisfactory as a preventive of repeated crime by the persons punished.

\footnotetext{
2 "Judicial punishment can never be administered as a means for promoting another good, either with regard to the criminal himself or to civil socicty." K.Avt, PmLosopm or LAw (Hastie's trans. I 887).

${ }^{3}$ Stzpihen, General View of the Criminal Law of England (2d ed. i8go) 99.
} 
Thus the drafting committee was faced at the outset with a difficult choice between objectives; or with the problem of evolving some plan of treatment which would accomplish both, which would be reasonably effective in deterring crime by others and would at the same time be more effective than present methods in preventing repeated crime by the persons treated. But any solution required consideration first of all of the reasons why the punishment of one criminal is supposed to deter potential criminals; then why and how it is supposed to affect the individual himself.

\section{Punitive Treatment Not Sufficiently Effective}

One conclusion stood out manifestly. The committee felt quite safe in assuming that the deterrent effect of punishment, either upon the person punished or upon others, could not be increased merely by increasing the harshness of the punishment and accentuating the victim's physical pain and suffering. History has made plain, even to the cursory reader, that the most horrendous punishments of a happily by-gone age were no more effective in either respect than their milder modern successors. No threat of mutilation, of pain, or of death appears ever to have deterred men from the pursuit of gain or honor, whether they climb the Chilkoot Pass over the f-ozen bodies of their predecessors, or face the flame-throwers of a bitter battlefield. The wisdom of thoughtful students suggests that if there be any deterrence through fear resulting from traditional law enforcement, it springs from the fear of disgrace, of ridicule as one who is unfit to mingle with his fellows, of injury to that psychological something which makes us desire rather to be like unto other men than unlike. Its force may spring also, as Aschaffenburg put it, from the fact that "the stamping of an act as an offense, the commission of which the State will prosecute with unrelenting severity, immediately arouses the feeling that the act is unsuitable, inadmissible, disreputable, contrary to duty. Thus general prevention operates rather quietly, slowly, and penetratingly, making the consciousness of right sharper, intensifying the general feeling for right and wrong, and is thus rather educative than directly deterrent."

All these deterrent influences the committee believed could be brought to bear without necessarily resorting to punishment in the common connotation of that term-without necessarily inflicting on each convicted individual some modicum of physical pain or suffering. Inasmuch as the harshest of penalties have been no more conducive of abstention from crime than our milder ones, it could fairly be assumed that the major deterrent is the conviction itself, rather than the penalty-is the stigmatizing, by conviction, of the convict as one who is reprobated by his fellow men because he is intolerably different from them. If to this stigmatization be added the probability that the convict may be segregated from society by institutional confinement for an indefinite time, neither the probability nor the duration of confinement being determinable in advance of conviction, there is brought to bear on the potential wrongdoer all the deterrent force, all the threat, except that of physical pain, ascribable to the traditional punitive procedure. And all this, as will become evident, is retained in the Youth Correction Act as proposed. 
Assuming, thus, that the mere physically punitive consequences of conviction could be altered, without materially derogating from the deterrent effect of the conviction on others than the one convicted, this question arose: How can the consequences of conviction best be altered so as to increase their preventive effect upon the convict himself?

Before the committee's answer to that question is stated, it should here be emphasized that none of the provisions of the Correction Act were motivated by sentimentality. There was no mere sympathy for the criminal as "a poor sick man who needs more help than harshness"; there was no desire to "turn the penitentiaries into country clubs." The one and only purpose in the committee's deliberations was that of hard-boiled practicality-to evolve whatever method of treatment, within the accepted bounds of humanity, would tend to prevent repeated crime more effectively than any other method would do it. To the extent that the proposed Correction Act departs from harshness of method, it does so not because harshness is cruel, but because mildness is more effective.

In determining what treatment to propose, the committee had first to inquire why the prevailing methods fail. For this failure they finally postulated four main causes. These faults are not characteristic of every institution, nor are all of them necessarily characteristic of every district. Some have been greatly mitigated here, others there. Hence the positing of certain faults as inherently characteristic of the traditional methods of treatment is in no way intended as a sweeping criticism of either institutions or administrators. It is just what it purports to be, a statement of faults inherent in the punitive system as such and avoided, where they have been avoided, only because the administrators of the system have wisely departed from the punitive tradition. The causes of the present system's failure to prevent repeated crime by the very persons who have been subject to it are these:

x. It too often subjects convicts of correctable character to deteriorative influences and character-destructive experiences.

2. It returns its victims to social freedom definitely less able to abstain from crime, and often less willing to do so, than before they were subject to it.

3. When it returns its victims to social freedom, it leaves them to face crime-productive pressures even stronger than they have previously known, with no help or encouragement in resistance thereto.

4. It necessarily returns to freedom ninety odd percent of those it deals with, regardless of their fitness for freedom or that freedom's danger to the community.

Heeding this history of failure of the traditional method, the committee sought to draft an act which would retain all that is good in the old method, while eliminating the causes of its failures and adding procedures better adapted to the ultimate end desired-the diminution of repeated criminality.

\section{The Mechanics of the Act}

But before discussing how the Correction Act is designed to remedy those causes of failure, it is necessary to explain the mechanics of its operation. The Act creates 
what it calls a Correction Authority of three members to administer its provisions. (\$4) Obviously the name is unimportant. Moreover, it should be clearly understood that in proposing the Act the Institute has not assumed that it will be, or should be, adopted anywhere in completeness and without alteration. Many of its details will necessarily be altered to fit the conditions existing in the particular state. Thus, in respect to the Correction Authority, the proponents of the Act recognize that this administrative group may well be larger in one state and smaller in another. In a state such as Michigan, which has a relatively new corrections law, a director of corrections protected by civil service, and a well-administered department, the Youth Correction administration may well be made a function of that already existing department. In other states it might better be set up as provided in the proposed Act.

Youths convicted of crime in any court, except a juvenile court, are required to be committed to this Authority, instead of being sentenced to penitentiary or reformatory. $(\$ \$ 12,13)$ A "youth" in this sense is a person who was less than 2r years of age at the time of the arrest from which the conviction resulted, and who was not proceeded against as a juvenile offender. (\$I2) This commitment to the Authority is the court's sentence of the convict. The period for which he is thus-sentenced is determined not by the committing court, but by the terms of the Correction Act. There is no question of any "double sentence," or of a sentence by the court and a subsequent sentence by the Authority. Under the terms of this Act there is just one sentence-that of the court in committing the convicted youth to the control of the Authority. The Authority then determines, within the limits fixed by the Act, how long the individual shall remain subject to its control. In this respect its power is essentially like that of the numerous state parole boards which determine how long a prisoner shall remain in the penitentiary; like the power, also, of the reformatory officials who now determine whether a youth committed by a juvenile court shall be released or kept in further confinement.

The Act sets out certain exceptions to this obligation of the court to commit to the Authority. ( $\$$ I3)

If the offense of which the youth is convicted is one for which a death penalty is mandatory in respect of persons over $2 \mathrm{I}$ years of age, the court must sentence the youth to death. So, too, if the mandatory penalty for adult offenders is life imprisonment, the youth must be so sentenced.

If the judge would have the alternative, in case of an adult, of the death penalty (or of imprisonment for life), or a term of imprisonment less than life, the court may either impose the more drastic penalty or commit the youth to the Authority.

If the court could sentence an adult to payment of a fine, without imprisonment, he may so sentence the youth, without commitment to the Authority.

If the offense is of the misdemeanor type which would subject an adult to possible imprisonment, but only for a maximum of 30 days, the court may sentence the youth to imprisonment for not over 30 days in some place approved by the Authority. ${ }^{4}$ But

\footnotetext{
'The Act docs not go into effect until the Authority has sertified to the Governor that it has set up the nccessary facilities for its operation. $\$ \mathrm{I} x$.
} 
if the youth has been previously convicted and the judge is satisfied that society will be best protected by committing the youth to the Authority, he may so commit him.

When a youth has been committed to the Authority it has a wide power of discretion in its treatment of him. The Act is, possibly, deficient in that it does not set up an appropriation of money for the creation of new or increased treatment facilities. Neither does it invest the Authority with control of existing penal and correctional institutions. On the contrary it expressly declares $(\$ 25(2))$ that

Nothing herein shall be taken to give the Authority control over existing facilities, institutions or agencies; or to require them to serve the Authority inconsistently with their functions, or with the authority of their offcers, or with the laws and regulations governing their activities; or to give the Authority power to make use of any private institution or agency without its consent; or to pay a private institution or agency for services which a public institution or agency is willing and able to perform.

The reason for not putting a specific appropriation provision in a model statute seems obvious. The reason for not investing the Authority with control of existing institutions is that the jurisdiction of the Authority is limited to youthful offenders, whereas the institutions which must be utilized by the Authority are employed in treatment of other types of offenders as well. Until a complete separation can be brought about between institutions used by the Authority and those used for other purposes, or until the Authority is given corrective jurisdiction over all convicts, it would be illogical to give the Authority control of the jointly used institutions.

But so far as concerns control of the persons committed to it, as distinct from control of institutions, the Authority is invested with broad powers. The Act states:

Public institutions and agencies are hereby required to accept and care for persons sent to them by the Authority in the same manner as they would be required to do had such persons been committed by a judge of a court of criminal jurisdiction. But no institution for the care of the insane or mentally defective persons shall accept a commitment by the Authority unless such commitment is in conformity with the laws requiring medical examination, certification by a judge, or other procedure. ( $\$ 25(3)$ )

The Authority is hereby given the right to inspect all public institutions and agencies whose facilities it is authorized to utilize and all private institutions and agencies whose facilities it is using. Every institution or agency, whether public or private, is required to afford the Authority reasonable opportunity to examine or consult with persons committed to the Authority who are for the time being in the custody of the institution or agency. $(\$ 25(4))$

Placement of a person by the Authority in any institution or agency not operated by the Authority, or the discharge of such person by such an institution or agency, shall not terminate the control of the Authority over such person. $(\$ 26(x))$

No person placed in such an institution or under such an agency may be released by the institution or agency unitil after approval of the release by the Authority, unless the institution or agency would have power under the law to release at its own discretion persons committed to it by order of a court. In the latter case, it may not release a person placed by the Authority until a reasonable time after it has notified the Authority of its intention to release him. $(\$ 26(2))$ 
When a person has been committed to the Authority it may (a) permit him his liberty under supervision and upon such conditions as it believes conducive to law-abiding conduct; (b) order his confinement under such conditions as it believes best designed for the protection of the public; (c) order reconfinement or renewed release under supervision as often as conditions indicate to be desirable; (d) revoke or modify any order except an order of discharge as often as conditions indicate to be desirable; (e) discharge him from its control when it is satisfied that such discharge is consistent with the protection of the public. $(\$ 30(x))$

Against this background of mechanics of operation of the Act it is possible to discuss the ways in which it is designed to alleviate the four evils from which results the failure of existing methods of treatment to prevent repeated criminality.

\section{The Avoidance of Character-Degrading Experience}

The most potent influence by which the criminal tendencies of a young man are encouraged, his character habits of law-abiding conduct reversed, is generally conceded to be the contacts and experiences of ordinary prison life. This is not to say that other degrading influences do not also have a part. Neither is it a suggestion that all places of confinement are alike in their hurtful effects. It is merely recognition of the common assumption that prison influences are more generally dangerous than others. Avoidance or mitigation of this evil is possible in several ways; a convict may not be sentenced to prison at all; he may be released from prison before its influence has wrought full havoc; he may be confined in an institution where the adverse factors. are at a minimum.

\section{a. Probation}

The idea of non-confinement, of suspension of sentence or its execution, of release on probation, is of course nothing new. It is already in operation to a varying extent in 40 states and the federal system. In only two respects do the proposals of the Correction Act go further than these already existing and approved practices.

Ordinarily the discretion to place a convict on probation instead of ordering him into actual confinement, rests in the trial judge. No two judges exercise the power similarly. In a single federal judicial district one finds one judge putting only $4 \%$ of his convicted defendants on probation, while another uses probation in $62 \%$ of his cases. ${ }^{5}$ Many states today have provision for some pre-sentence investigation through which the judge can make a guess at the need and wisdom of releasing the defendant on probation; but so multiple are the possible factors involved and so relatively meager is the information provided in the average case that the judicial choice can not hope to be more than an intelligent guess at best.

The Act proposes to lessen this evil by relieving the busy and not particularly trained judge of the burden of such decisions. At the same time, be it noted, the Act does not deprive the judge of the pleasure-and what some have frankly called the

\footnotetext{
'McGuire and Holtzoft, The Problem of Sentence in the Criminal Law (1940) 4 Fro. Probation 22. Sce also Gaudet, Individual Differences in the Sentencing Tendencies of Judges (1938) Aronves of Pinlosophy, No. 230, p. I9.
} 
political profit - of refusing to order a youth into confinement when, as a preliminary judgment, he thinks confinement unnecessary. The Act expressly provides that whenever a judge commits a youth to the Authority "he may direct that he be left at liberty until otherwise ordered by the Authority under such conditions as in the judge's opinion will insure his submission to any orders which the Authority may issue." ( $\$ \mathrm{r} 8)$ This provision grew out of a recognition that for some youths any actual imprisonment, even temporarily while the Authority was gathering the data on which to base its further orders, might foster criminal tendencies rather than arrest them. This judicial power to order immediate release on probation seemed necessary as a preservation of the best in the present practices of probation and suspended sentence.

But whenever a youth has been committed to the Authority-whether the judge orders him left at liberty or directs that he be at once confined ${ }^{6}$-it becomes the duty of the Authority, through its agents, not necessarily by the members of the Authority itself, forthwith "to examine and study him and investigate all the pertinent circumstances of his life and the antecedents of the violation of law because of which he was committed." ( $\$ 28)$ From that investigation the Authority is then in a position to determine, more wisely than any judge could reasonably be expected to do, whether or not the youth should be released-or continued-on probation; it has data not usually available to judges and it operates through agents trained in that sort of prognostication of behavior.

In another aspect also the Act is an improvement over most existing legislation respecting probation. While the statutes vary greatly, the majority specify certain offenses after which the person convicted can not be placed on probation. But the list of these offenses differs. California specifies I6, Illinois I2, Indiana 6, Kentucky none. Louisiana specifies bigamy among others for which probation is not allowed, but does not forbid it after larceny; Kansas forbids it after conviction of larceny of an automobile, but permits it after conviction of bigamy; Iowa does not preclude it after either, but specifies treason, which the others do not; some states consider the possession of a deadly weapon the basic reason for refusal of probation, others ignore that fact. All in all, it is impossible to avoid the conclusion that there is no fundamental reason at all why probation is forbidden after conviction for this, that, or the other specified offense. The confusion suggests merely failure of the legislators to appreciate the real reason for any probation-which is expressed in the statutes themselves to be that a convict may wisely be put on probation "where it appears to the satisfaction of the court that the defendant is not likely again to engage in an offensive or criminal course of conduct, and that the public good does not require that the defendant shall suffer the penalty imposed by law."

The Correction Act makes this already accepted principle the basis of its provisions, and permits release on probation whenever those conditions exist and whenever the

\footnotetext{
- The Authority is required to designate proper places of confinement before the Act can come into operation. $\$ 11$.
} 
Authority is satisfied-in the words of the Oregon statute-that "the best interests of the public as well as the defendant will be subserved thereby." It has never been demonstrated, nor could it be, that the public has been better protected in states where the use of probation is drastically limited than it is protected in states having no such limitations. Hence the Act sets out no specific offenses for which probation is not possible, but permits it whenever the Authority is satisfied that the interests of society will best be served by probation.

\section{b. Parole}

Another procedure designed to minimize the evil effects of actual imprisonment is the now common practice of release on parole when confinement appears no longer necessary for the public safety. The only power of importance given by the Correction Act to the Authority which is not already commonly exercised by parole boards is that of releasing promptly, without any required minimum of time, whenever release seems conducive to the good of the individual and of the public as well. Even this power is already vested in the parole boards of at least half a dozen states, so that the Correction Act is no more than following the already developed trend of progress in this respect.

\section{c. Separation of Prisoners}

A third procedure for the minimizing of character-deteriorative influences is proper segregation of different character types during the period of confinement. Some states have no specific legislative provision for such segregation. Some provide merely that male and female convicts shall be kept separate; others that white shall not be confined with black. Many states have established separate and distinct institions in which youthful offenders are to be kept apart from those of mature years. Illinois invests its correction authorities with power to establish "divisions of the penitentiary system," which are to be set up "in the light of considerations relating to age and character of the inmates, the necessity of preserving first offenders from contact with recidivists and such other criteria of classification as may be dictated by penological science. ..." Michigan, too, obligates its department of correction to make careful study of every prisoner "to the end that he may be confined in the institution suited to the type of rehabilitation required in his case."

Though these latter are the unusual type of statute, they are also the more modern; they exemplify the trend which has already developed. The proposed Act does not supply the Correction Authority with funds, but it does empower that body, when funds are available, to set up whatever institutions may be required for proper separation of prisoners. (\$27) Moreover, it requires the Authority to study each youth committed to it and to determine in which of the existing state institutions he can be confined with most hope of benefit, instead of injury to the likelihood of his abstention from crime in the future. $(\$ 28)$ 
Rehabilitation for Law-Abiding Existence

One reason for the failure of mere punishment to prevent repeated criminality by the person punished, is that while the pain and suffering imposed may possibly create in its victim a desire to live within the law thereafter, it does not strengthen his ability to do so. The causes of crime are too multifarious for analysis, but they do boil down into two generalizations; either a normally resistant person is subjected to abnormal pressure toward crime; or else an abnormally unresisting person yields to normal pressure. The most that punishment as such can even pretend to do is to strengthen the will of resistance. One may gravely question that it really does even that; but even in the most unrealistic of theories it is not supposed to do more than that. By no stretch of imagination can punishment be supposed to lessen the pressures to which its victim may be exposed.

These pressures toward criminal conduct may be internal of the individual-a deficiency in the blood stream content leading to abnormal cravings; a chronic, but curable, inflammation of the mons veneris causing abnormal sexual desires. Or they may be external to himself-established and not practicably avoidable criminal associations, for example. An inability to maintain honest self-existence in a competitive world may have driven one youth to crime, and will inevitably continue so to drive him as long as the inability continues. Another's criminality may have been the reaction of an inferiority complex; a psychological condition, correctable by treatment or change of environment, perhaps, but never by mere physical or mental punishment.

If the will to abstain from crime were the only real determinant of conduct in that respect, it might suffice for the prevention of crime to strengthen that will enough. Perhaps a sufficiency of will is all that is needed to keep any individual in the paths of rectitude; the writer has no wish to enter the controversy which centers about that problem. But any assumption that will to abstain is enough, necessarily presupposes that there is will enough. If will is enough, can mere punishment create enough will?

The answer is that punishment itself never in all of history has been sufficient to that end. The failure of punishment to put an end to repeated crime even by the person punished can not be attributed to the mildness of modern penalties. The death perialty did in truth stop further crime-but not because it was a "lesson" to the victim. Nothing less than death, not even the fearful barbarities of a time which is now past, ever effectively put a stop to repeated criminality. As a matter of truth there is evidence, if not proof, that the ultimate effect of punishment is to weaken the will toward law-abiding conduct, not to strengthen it.

So, conceding, if one wishes, the theoretical postulate that crime is no more than a matter of deficient will to abstain therefrom, the postulate remains no more than a splendid theory until its proponents can demonstrate a method of begetting that will in reality. Punishment, by physical pain and mental suffering, has never yet succeeded in that end, and in any sensible presumption never will succeed. From this latter 
premise a correlative premise is ineluctable-if we cannot sufficiently strengthen the will to resist pressures toward crime, the alternative is to reduce those pressures.

\section{a. Diminishing the Economic Causation of Crime}

That means, of course, first to discover what are the pressures upon a particular individual, second to discover a means for reducing them. Insofar as pressures are the operation of social conditions, it is scarcely the function of criminal law enforcement agencies to cope with them. An undue availability of intoxicating liquor, abnormal slum conditions, a group psychology which condones or even encourages certain types of crime-all such conditions as these presumably must be corrected through other agencies. But whenever the pressure results from a peculiarity of the individual himself, the possibilities are altogether different. The enforcement agencies of the criminal law are the very agencies that do deal with him. Theirs is the opportunity to study the particular cause which drove him into crime. Theirs is the duty, when that cause is found, to eliminate it if they can. To strengthen also the individual's will is a wise procedure when it is possible; to diminish the forces which overcame his will and are likely to overcome it again is even wiser.

In actual practice this latter process would necessarily deal largely with bettering the individual's capacity for honest self-support. If it be true, as so frequently asserted, that poverty is a potent cause of crime; if there is merit in the now common effort to educate people generally in useful trade skills, then there is peculiar value in so training persons who have yielded to the pressures of incapacity in those skills, and peculiar need for so training them. Just because "punishment" has been so lamentably unsuccessful-not because it is cruel, or is morally undeserved, nor for any sentimental reason, but just because it is not satisfactorily successful-it must largely yield place to education and training in increased ability for law-abiding life.

This necessity has already been clearly recognized in the legislation of several states; though more or less academically recognized, inasmuch as funds for operation of the newer policy have not been provided.7 The Illinois statutes, for example, provide that prisoners shall be employed "so far as practicable in occupations in which they will be most likely to obtain employment after their discharge from imprisonment" and their work "shall be directed with reference to fitting the prisoner to maintain himself by honest industry after his discharge." Indiana authorizes training "in the mechanical arts." Massachusetts authorizes such prison industries as will enable the prisoners to learn valuable trades. The statutes of other states show less cognizance of this need. Alabama directs that prisoners be employed at such work as the authorities may determine. In Mississippi "for the use of the penitentiary" the superintendent may establish a blacksmith shop, wagon shop, shoe and harness shop, grist mill, brick and tile factories, and a tailoring shop. Women con-

\footnotetext{
${ }^{7}$ Some states, such as California and Michigan, have made special financial provision for the purpose.
} 
victs may manufacture clothing for convicts. Some states have no provision, or only a provision that the prisoners may be kept at "hard labor."

The Correction Act is in this particular respect no more advanced than is some of that already existing and accepted legislation. The Act, of itself, appropriates no funds, but it gives the Authority power, when funds are available, to set up all agencies and institutions necessary to its corrective work; (\$27) and it specifically provides that the Authority may require any person committed to it to participate "in vocational, physical, educational and corrective training." ( $\$ 3$ I) Insofar as facilities for such training already exist, the Authority is permitted to make use of them. (\$25)

\section{b. Correcting Other Causes of Crime}

The fact that an individual's criminality may be the product of some abnormal, but correctable, physical or mental condition has not been so well recognized in existing legislation as has his possible need for training in self-support. There are provisions in occasional statutes for "psychiatric examination," and in most states there is a common provision for medical and surgical aid to prisoners in need of it. But in no statute is there apparent recognition of the probabilities of crime prevention by means of medicine or surgery. Neither, it must be admitted, does the Correction Act state that possibility so explicitly as one could wish; but recognition of the possibility is implicit in the Act and the Authority is required to "study" each person committed (\$28) and is expressly invested with power not only to utilize education and training in trade skills, but also "to make use of other methods of treatment conducive to the correction of the person and to the prevention of future violations of law by him." (\$3I)

So far as repeated crime may be a consequence of environment and companionship, the Authority has power-so long as a youth is still under its jurisdiction, even though he be released on parole from confinement-" to require such conduct and modes of life as seem best adapted to fit him for a return to full liberty without danger to the public welfare." ( $\$ 3 \mathrm{I})$

\section{Assistance after Release}

In the way of provision for assistance to persons who have been released from imprisonment, the Correction Act is far ahead of existing legislation; but not at all in advance of what all students of the problem have long been advocating. The point is that when men are released from prison into social freedom they face a problem of honest livelihood far more difficult than anything they have experienced before. The man who has never been in jail treads a primrose path of life compared to the rough course which the "ex-convict" must struggle through. The latter has been "out of work" for months or years, and it is difficult enough in normal times for even the man with' a good reputation to thrust himself back into a place of employment. Many large employers have an established policy of refusal to employ 
ex-convicts at all; small employers fear to do so. In times of war "defense industries" close their gates to him; the army and navy are forbidden by statute to accept him as a volunteer for death.

Large-scale offenders who have embezzled thousands or have mulcted investors of millions may get jobs as managers of some friend's country estate, or may even be met at the Nashville station by a brass band and an automobile parade. But for every one so welcomed, thousands are finally released with no money, no job, and no prospect of one. What friends they have are the associates with whom they originally embarked into crime; they are the friends-and the repeated influences toward repeated crime-to whom the released convict must return. It is the writer's guessthere are no data from which to do more than guess-that this one factor, the factor of lack of real assistance in honest living after release, accounts more than any other one circumstance for the appalling percentage of relapse into fresh criminality.

Existing law, except in two states, makes no real provision for help to the released convict. The conventional statute is like that of Washington which provides for each discharged convict a suit of clothes to cost not more than \$10, transportation by the cheapest route to place of sentence, and $\$ 5$ in money. The Florida statute adds insult to injury by saying that the $\$ 5$ is given him "to provide the necessities of life until he can procure work." Five dollars in these days for that purposel In his \$ro suit, without money for bus fare to the factories, without money for the necessary tools of his trade, without money for the union dues without which his labor leaders will not permit him to work, what can he do but hope that this time he will not be caught?

Even when the convict is released on parole the actual assistance he gets is not much more helpful in fact. Some state laws provide that he cannot be paroled unless he has a job and a home awaiting him. In many states, too, it is the practice of parole boards to find jobs for their parolees before the release is granted. But when that first job terminates-and employment does too often end without fault of the employee-what then? The Kentucky statute is perhaps the most explicit. The state's two parole agents, employed at \$roo a month, are expected to find employment for prospective parolees, "to assist them in keeping employed at all times while so on parole ... to counsel, aid and encourage such paroled prisoners and assist them to become self-sustaining and useful members of society; to investigate and report on breaches of parole. ..." But of power to assist them with funds, of authority to furnish them beds at night, food, tools, carfare, union cards, the statute says nothing; nor does it provide funds for such purposes. The more conventional statutes are even worded in terms not of help, but of watchfulness.

There are many private charities which, by assistance to persons just released from prison, do an incalculable amount of social good by preventing relapses into crime. But they are not state-supported. The Correction Act again does not set up any appropriation of money for the purpose, but it clearly recognizes the need, and it explicitly invests the Authority, when funds can be secured, with power to set up 
"agencies and facilities designed to aid persons who have been discharged by the Authority from its control in finding employment and in leading a law-abiding existence." This is in addition to a similar power given it in respect of parolees. (\$27)

\section{Segregation until Release Is Safe}

When a Michigan prisoner, Dominic Piccone, reached the end of a four-year penitentiary sentence, the prison psychologist advised the authorities against his release because he showed definite homicidal tendencies. But the authorities had no alternative under the state law; the punitive sentence had been served, and Piccone was released. Within two weeks he had inurdered three good citizens.

That is only an extreme case out of many where release has been obligatory under the law, despite the fact that grave danger to the public security was obvious from such release. Even in the case of misdemeanors only, a system is downright absurd which allows the imprisonment, release, reimprisonment and rerelease of one man for forty, fifty, seventy, a hundred successive times. The cost in time, effort and money is terrific; the nuisance to the public is incalculable and should be intolerable. Yet existing law absolutely requires release even until the hundred and first time and beyond. ${ }^{8}$

A citizen who is a public menace, even though not homicidal, because of any state of mind which can be dubbed "insanity" can be segregated, under existing law, for so long as his dangerousness continues. Moreover the question of his continued dangerousness, like his original segregation, is determinable without the right to jury trial. Yet that method of protecting the public safety against his particular dangerousness is established and accepted as sound. So, too, a "Typhoid Mary" can be confined in the hospital on Welfare Island for year after year until death ends her threat to the public health, without the right to jury trial. Even in the case of juvenile antisocial tendencies, extremely young offenders can be institutionalized by judicial order, there to remain until they are twenty-one, without right to release unless and until the authorities in charge are satisfied that release will be compatible with public good.

The Correction Act merely proposes that the evil resulting from frequent release of persons who are known to be criminally dangerous be mitigated, by applying to the situation the same practical philosophy by which the public is protected against juveniles, against disease carriers, and against the psychiatrically peculiar-but to apply it with even greater safeguards against abuse than are common to those procedures.

\section{a. Existing Statutes}

To a limited extent the existing criminal law has already made a start in this direction. The so-called fourth-offender laws of many states now provide a life-long segregation for persons wha have been three times released after felony convictions and have offended yet again. The basis of these statutes appears to be punishment

\footnotetext{
"There is in fact more than one reported case of over roo releases.
} 
rather than segregation; they are far harsher than anything in the proposed Act, because they do not permit release even when release would obviously be beneficial to the individual and harmless to the public. But they do demonstrate a recognition of the wisdom of continued segregation.

Another type of already existing statute clearly evidences a legislative realization of the need for continued segregation of people who are dangerous because of their criminal tendencies, even though they are neither insane, nor disease carriers, nor ferocious juveniles. In both Michigan and Illinois, people convicted of sex crimes, who show tendencies toward repeated sex offenses, can be indefinitely segregated "until cured" of their dangerous tendencies, even though in the words of the statute they are "not insane." In New York any "mentally defective" youthful criminal can be segregated until cured of his dangerousness. Just why these statutes are limited to "sex criminals" is not apparent; an arsonist who "though not insane" shows tendencies toward repetition, or a thief who is likely to persist, or a killer who, though not insane, shows homicidal tendencies, are surely as dangerous to the peace and safety of society as a sexual exhibitionist. All that the Correction Act proposes is that this already begun progress toward public protection by confinement of persons known to be dangerous to it shall be extended to its logical application. But one thing should be strongly emphasized-the Act also sets up more careful safeguards against possible abuse of the process than are to be found in the already accepted laws.

\section{b. The Provisions of the Act}

In the first place the Act absolutely requires that the Authority make prompt and thorough study of every person committed to it, for the purpose of determining what sort of treatment is most likely to fit him for early release. That examination of each individual must be periodically repeated; there can be no "forgotten man" under the Act. If the examination and renewed determination of proper rehabilitative treatment is not so made, the individual is given a right to petition the court for an order of discharge. The discharge must be granted unless the Authority can satisfy the court, after a full hearing of both sides, that further control is necessary. $(\$ 28(4)$ )

Every person must be released by the Authority as soon as it believes "there is reasonable probability that he can be given full liberty without danger to the public." (\$29(2)) This section of the Act does not purport to set up rule-of-thumb standards by which the Authority must determine fitness, because no such standards have yet been discovered. The fitness for discharge is necessarily left to the intelligent discretion of the Authority, just as existing law leaves it to the discretion of the judges when they suspend sentences, to parole boards, to administrators of juvenile institutions, and to the directors of hospitals for diseased or the insane.

But the Authority's discretion in refusing to order release is carefully limited. With certain exceptions which will be discussed, every person who is committed 
because of a minor offense for which the "punishment" of an adult would be not over 30 days imprisonment must be discharged before he becomes 2I years old, or within 3 years of his commitment. ( $\$ 32)$ If a possible 3-year imprisonment for a youth in cases where an adult could be held only 30 days seems appalling, it must be remembered first that the 3 years is not obligatory; the youth may be released in 3 hours. Next, the only youth who can be committed for such an offense is one who has been previously convicted one or more times and who the trial judge believes cannot be cured of his criminal propensities without treatment by the Authority. $(\$ 13(i))$ Michigan already has a statute to the effect that a person three times convicted of misdemeanor as a disorderly person can be imprisoned for two years. In the third place, the adult is being punished in the, usually vain, hope that he will voluntarily reform, and a relatively mild punishment is all that he deserves. But the youth is not being "punished" in this sense any more than the blameless mentally defective, insane, or disease-carrying person is being punished by segregation from society. The youth, like those others, is being segregated, not in retribution for the particular offense, but because like those others he has shown that his continued liberty is a threat to the public peace and security. He is to be segregated so long, but only so long, as that threat continues; but with the exception to be discussed, the Authority must assume him to be no longer dangerous and must release him as soon as the stated time has elapsed.

So, too, youths who have been committed because of more heinous offenses must be released by the time they reach 25 years of age. Their social dangerousness is assumed to be terminated by then. $(\$ 32)$

But if the Authority is satisfied that any person under its control ought not to be released even at the times stated, it is authorized to go into court and prove, or try to prove, that release would be dangerous. The provision of the Act is as follows:

Whenever the Authority is of opinion that discharge of a person from its control at the age limit stated in Section 32 would be dangerous to the public it shall make an order directing that the person remain subject to its control beyond that period and shall make application to the [appropriate] court for a review of that order by the court. The order and application shall be made at least six months before the time for discharge stated in Section 32. The application shall be accompanied by a written statement of the facts upon which the Authority bases its opinion that discharge from its control at the time stated would be dangerous to the public, but no such application shall be dismissed nor shall the order be disapproved, merely because of its form or an asserted insufficiency of its allegations; every order shall be reviewed upon its merits. (\$33)

If the Authority applies to the court for review of an order as provided in Section 33, the court shall notify the person whose liberty is involved, and if he be not sui juris, his parent or guardian if practicable, of the application and shall afford him an opportunity to appear in court with the aid of counsel and of process to compel attendance of witnesses and production of evidence. When he is unable to provide his own counsel, the court shall appoint counsel to represent him. $(\$ 34(\mathrm{I}))$ 
If after a full hearing the court is of opinion that discharge of the person to whom the order applies would be dangerous to the public because of his mental or physical deficiency, disorder, or abnormality, or because of his lack of improvement under corrective training and treatment, the court shall confirm the order of the Authority. If the court is of opinion that discharge of the person from continued control of the Authority would not be dangerous to the public the court shall disapprove the order of the Authority and shall order the person to be discharged from its control. $\left(\$_{34}(2)\right)$

If the court authorizes a continuance of the Authority's control, the individual whose liberty is affected is by the Act given a right of appeal to a higher court. $(\$ 36)$ If the lower court's action is affirmed on appeal, the Authority's control continues so long as necessary, but not to exceed two years in cases of commitment for minor violation, or five years in other cases; after which time the person must be discharged unless a new order is made by the court. $(\$ 35)$

Again no rules are set out in the Act by which the court shall determine the individual's fitness or unfitness for social liberty. It is necessarily assumed that they will be essentially the same as those by which, under the accepted existing legislation, the fitness of a "sex criminal" for release is determined, or the fitness of any criminal for release on probation or parole. The non-existence of any precise rule of thumb is no more a fault in the proposals of the Correction Act than it is a condemnation of the existing probation, parole, juvenile correction, and sex criminal statutes. On the other hand, the collateral provisions of the Correction Act raise greater protection against abuse than is found in those statutes, because the Act provides for judicial hearings to review the judgments of the Authority, and provides for automatic release unless the necessity for further control is affirmatively proved.

The proposed Correction Act, then, is not a radical offer of new and untried practices, supported only by theory. On the contrary it does no more than gather together practices actually in effect and accepted as wise under the legislation of various states, and other practices-such as effective assistance in law-abiding conduct after release-which, though not yet in utilization under governmental authority, have been followed by private agencies and are approved by all students of the problem. Its essential value as a proposal for legislation is that it gathers together these desirable but scattered practices, not all of which are yet followed in any one state, and integrates them into a coordinated procedure for diminishing that burden of repeated criminality from which the public now suffers. ${ }^{9}$

\footnotetext{
DIf one qucries why the Act is confined to tratment of convicted youth only, the answer is threefold;-The initial burden on the Authority of so dealing with all convicted persons would be practically insupportable-a moderate beginning is wise. Opposition which will stop its ears to reason concerning adult criminals will often accept a similar proposal concerning youth. So much of adult criminality has its beginning in youth that, if youth can be taught not to rcpeat, the crimes of maturity will be of relatively litue moment.
} 